\title{
Protective effect of rhein against oxidative stress-related endothelial cell injury
}

\author{
XIAN-FENG ZHONG ${ }^{1}$, GUI-DONG HUANG ${ }^{2}$, TING LUO ${ }^{1}$, ZE-YUAN DENG $^{1}$ and JIANG-NING HU ${ }^{1}$ \\ ${ }^{1}$ State Key Laboratory of Food Science and Technology, Nanchang University, Nanchang, Jiangxi 330047; \\ ${ }^{2}$ State Key Laboratory of Food Science and Technology, School of Food Science and Technology, \\ Jiangnan University, Wuxi, Jiangsu 214122, P.R. China
}

Received November 1, 2011; Accepted January 12, 2012

DOI: $10.3892 / \mathrm{mmr} .2012 .793$

\begin{abstract}
Endothelial cell injury caused by reactive oxygen species (ROS) plays a critical role in the pathogenesis of atherosclerosis. Therefore, phytochemicals or antioxidants that inhibit the production of ROS have clinical value for the treatment of atherosclerosis. Rhein is one of the most important active components of rhubarb (Rheum officinale), a famous traditional Chinese remedy that possesses potent antioxidant properties through undefined mechanism(s). The aim of the present study was to determine whether rhein inhibits hydrogen peroxide $\left(\mathrm{H}_{2} \mathrm{O}_{2}\right)$-induced injury in human umbilical vein endothelial cells (HUVECs). The oxidative injury model was established with $\mathrm{H}_{2} \mathrm{O}_{2}$. HUVECs were treated with different concentrations of rhein in the presence/absence of $\mathrm{H}_{2} \mathrm{O}_{2}$. The protective effects of rhein against the injury caused by $\mathrm{H}_{2} \mathrm{O}_{2}$ were evaluated. HUVECs incubated with $200 \mu \mathrm{mol} / 1 \mathrm{H}_{2} \mathrm{O}_{2}$ had significantly decreased cell viability, which was accompanied by cell apoptosis and upregulated Bid and caspase-3, -8 and -9 mRNA expression. Meanwhile, $\mathrm{H}_{2} \mathrm{O}_{2}$ treatment induced a marked increase in malondialdehyde (MDA) and lactate dehydrogenase (LDH) content and decreased the nitric oxide (NO) content and nitrogen oxide synthase (NOS), superoxide dismutase (SOD) and glutathione peroxidase (GSH-PX) activity. However, pre-treatment with different rhein concentrations $(2,4,8$ and $16 \mu \mathrm{mol} / \mathrm{l})$ significantly increased the viability of $\mathrm{H}_{2} \mathrm{O}_{2}$-injured HUVECs, decreased the MDA and LDH content, increased the NO content and NOS, SOD and
\end{abstract}

Correspondence to: Professor Ze-Yuan Deng, State Key Laboratory of Food Science and Technology, Nanchang University, Nanchang, Jiangxi 330047, P.R. China

E-mail: zeyuandeng@hotmail.com

Abbreviations: AS, atherosclerosis; HUVECs, human umbilical vein endothelial cells; ROS, reactive oxygen species; MDA, malondialdehyde; LDH, lactate dehydrogenase; NO, nitric oxide; SOD, superoxide dismutase; NOS, nitrogen oxide synthase; GSH-PX, glutathione peroxidase; qRT-PCR, quantitative real-time polymerase chain reaction

Key words: rhein, endothelial cells, oxidative injury, protection
GSH-PX activity in a dose-dependent manner and resulted in significant recovery from $\mathrm{H}_{2} \mathrm{O}_{2}$-induced cell apoptosis. In addition, the results of the qRT-PCR indicated that pre-treatment with rhein downregulates the expression of Bid and caspase-3, -8 and -9 mRNA, which plays a key role in $\mathrm{H}_{2} \mathrm{O}_{2}$-induced cell apoptosis. The present study shows that rhein protects endothelial cells against oxidative injury induced by $\mathrm{H}_{2} \mathrm{O}_{2}$, suggesting that rhein is a potential compound for the prevention and treatment of atherosclerosis.

\section{Introduction}

Cardiovascular disease (CVD) is the primary cause of morbidity and mortality worldwide (1). Atherosclerosis (AS), a chronic inflammatory disease that results in the deposition of oxidized lipoproteins that form fatty plaques, accounts for nearly $75 \%$ of all deaths from CVD $(2,3)$. Vascular inflammation, especially at the endothelium cell level, has been shown to play a pivotal role in the initiation, progression and clinical complications of AS (4).

Endothelial cells regulate cardiovascular health and control the elasticity of vessels. Injury of endothelial cells is the first stage of AS, and oxidative stress is regarded as a critical pathogenic factor in endothelial cell injury (5). Oxidative stress is mainly caused by the excessive accumulation of reactive oxygen species (ROS), which include hydrogen peroxide $\left(\mathrm{H}_{2} \mathrm{O}_{2}\right)$, superoxide anions $\left(\mathrm{O}^{2-\bullet}\right)$ and hydroxyl radicals $\left({ }^{\circ} \mathrm{OH}\right)$. ROS are continuously produced in cells as products of cellular oxidation-reduction processes and as the mechanisms of biophylaxis (6). Numerous studies have shown that exposure to ROS is one of the main causes of endothelial cell injury (7). Among them, $\mathrm{H}_{2} \mathrm{O}_{2}$ is known to be one of the common ROS, which easily penetrates the plasma membrane and affects neighboring cells as well as $\mathrm{H}_{2} \mathrm{O}_{2}$-producing cells. By itself, $\mathrm{H}_{2} \mathrm{O}_{2}$ does not initiate lipid peroxidation, does not oxidize DNA or amino acids, and has been extensively used to induce endothelial cell injury in in vitro models (7-9).

Rhein (4,5-dihydroxyanthraquinone-2-carboxylic acid), the active metabolite of diacetylanthraquinone, is one of the most important active components of rhubarb (Rheum officinale), a famous traditional Chinese remedy (10). Rhein has antibacterial (11), antitumor and anti-inflammatory properties (12). Notably, rhein inhibits superoxide anion production in a 
dose-dependent manner (13) and the proliferation of vascular smooth muscle cells (14).

In the vascular system, rhein is beneficial for the prevention of AS by protecting endothelial cells from damage (15). In the present study, an oxidative injury model was established using $\mathrm{H}_{2} \mathrm{O}_{2}$, and the effect of rhein on oxidative damage to human umbilical vein endothelial cells (HUVECs), as well as the potential underlying mechanism, were investigated.

\section{Materials and methods}

Materials. HUVECs were obtained from the College of Medicine of Nanchang University (HUVEC-12). The study was approved by the Ethics Committee of Nanchang University (China). Fetal calf serum (FCS), Dulbecco's modified Eagle's medium (DMEM) and serum-free medium were purchased from Gibco (Invitrogen, USA). Trypsin and 3-(4,5-dimethylthiazol-2-yl)-2,5-dipheyltetrazolium bromide (MTT) were purchased from Sigma-Aldrich (USA). Rhein was obtained from the National Institute for the Control of Pharmaceutical and Biological Products (Beijing, China).

Cell culture. HUVECs were cultured in DMEM containing $10 \%$ FCS under standard conditions [humidified atmosphere, $\left.5 \%(\mathrm{v} / \mathrm{v}) \mathrm{CO}_{2}, 37^{\circ} \mathrm{C}\right]$. Upon reaching confluence, the cells were harvested by treatment with $0.25 \%$ trypsin and $0.02 \%$ EDTA for $3 \mathrm{~min}$ and replanted. The medium was changed every 2 days and the cells from the fourth passage were used for all subsequent experiments. The cell number was determined by classic hemocytometry.

Effect of rhein on the proliferation of HUVECs (MTT assay). The HUVECs were seeded at a density of $5 \times 10^{3}$ cells/well in 96-well cell-culture plates and pre-incubated for $24 \mathrm{~h}$ before DMEM was replaced with serum-free medium. After $8 \mathrm{~h}$ of incubation, the cells were treated with serum-free media containing rhein $(2,4,8,16,32$ and $64 \mu \mathrm{mol} / \mathrm{l})$ for $24 \mathrm{~h}$. Rhein in $0.01 \mathrm{M}$ phosphate buffer ( $\mathrm{pH}$ 7.2) was used as the control.

Following treatment, the serum-free media containing rhein were removed and fresh media were added; the cells were then incubated for $4 \mathrm{~h}$ to stabilize. Finally, the cells were incubated with $100 \mu \mathrm{l}$ MTT solution $(5 \mathrm{~g} / \mathrm{l})$ for $4 \mathrm{~h}$. The media were removed and the water-insoluble formazan crystals that formed in the living cells were dissolved in $100 \mu \mathrm{l}$ DMSO. The absorbance was recorded at $490 \mathrm{~nm}$ using a Thermo Scientific Multiskan MK3 Microplate Reader (Thermo Fisher, USA). Six independent replicates were performed for each experiment.

Effect of rhein on the $\mathrm{HUVECs}$ with $\mathrm{H}_{2} \mathrm{O}_{2}$ treatment. The cells were cultured under the conditions described above. The oxidative injury model of HUVECs was established using $\mathrm{H}_{2} \mathrm{O}_{2}$, which was designated as the $\mathrm{H}_{2} \mathrm{O}_{2}$ group. The HUVECs were randomly divided into the control, $\mathrm{H}_{2} \mathrm{O}_{2}$ group and five rhein groups $(1,2,4,8$ and $16 \mu \mathrm{mol} / 1 \mathrm{rhein}+200 \mu \mathrm{mol} / 1$ $\mathrm{H}_{2} \mathrm{O}_{2}$ ). The HUVECs in the $\mathrm{H}_{2} \mathrm{O}_{2}$ group were incubated for $8 \mathrm{~h}$ in medium containing $\mathrm{H}_{2} \mathrm{O}_{2}(200 \mu \mathrm{mol} / \mathrm{l})$. In the rhein groups, the cells were pre-incubated for $24 \mathrm{~h}$ with different final concentrations of rhein $(1,2,4,8$ and $16 \mu \mathrm{mol} / \mathrm{l})$ and then exposed to $200 \mu \mathrm{mol} / 1 \mathrm{H}_{2} \mathrm{O}_{2}$ for $8 \mathrm{~h}$. Finally, the effect of rhein on the HUVECs with $\mathrm{H}_{2} \mathrm{O}_{2}$ injury was measured with an MTT assay, as previously described. In the present study, we carried out the concentration-dependent analyses of the survival rate of HUVECs induced by $\mathrm{H}_{2} \mathrm{O}_{2}$. When $\mathrm{H}_{2} \mathrm{O}_{2}$ concentration was $>200 \mu \mathrm{M}$, the survival rate decreased by $23 \%$, significantly different to the control $(\mathrm{p}<0.05)$, which suggests that $\mathrm{H}_{2} \mathrm{O}_{2}$ induced cell injury. Regarding experimental data processing, $200 \mu \mathrm{M}$ of $\mathrm{H}_{2} \mathrm{O}_{2}$ was chosen to establish the oxidative stress model.

Effect of rhein on LDH, MDA, NOS, NO, SOD and GSH-PX of HUVECs. The release of nitric oxide (NO) and lactate dehydrogenase (LDH), the content of malondialdehyde (MDA), and the activities of superoxide dismutase (SOD), nitrogen oxide synthase (NOS) and glutathione peroxidase (GSH-PX) were determined with assay kits (Jiancheng Bioengineering Research Institute, Nanjing, China), following the manufacturer's instructions.

Effect of rhein on the apoptosis of HUVECs. An Annexin V-fluorescein isothiocyanate (FITC) apoptosis detection kit (KeyGEN, Nanjing, China) was used for the assay, which was determined by flow cytometry. The cells were collected by trypsinization and centrifuged at 2,000 rpm for 5 min. Subsequently, the cells were washed twice with PBS (pH 7.2) and centrifuged at 2,000 rpm for $5 \mathrm{~min}$. The cell pellets were resuspended in fluorochrome solution containing propidium iodide (PI) and Annexin V-FITC. After $5 \mathrm{~min}$, the cells were analyzed with BD FACSCalibur ${ }^{\mathrm{TM}}$ flow cytometry system (Becton-Dickinson, USA). All tests were carried out in triplicate.

Quantitative real-time polymerase chain reaction ( $q R T-P C R$ ) for the mRNA expression. Total RNAs were isolated from HUVECs using TRIzol reagent (Invitrogen), and $1 \mu \mathrm{g}$ of RNA was reverse-transcribed using the PrimerScript ${ }^{\mathrm{TM}}$ RT-PCR kit (Takara code DRR014A), according to the manufacturer's protocol. qRT-PCR was performed to determine the expression levels of genes, such as Bid, as well as caspase-3, -8 and -9, using SYBR Premix Ex Taq ${ }^{\mathrm{TM}}$ (Takara code DRR041A) in the ABI 7900HT Real-Time PCR system (Applied Biosystems, USA). The following PCR conditions were used: $95^{\circ} \mathrm{C}$ for $30 \mathrm{sec}$, followed by 40 cycles at $95^{\circ} \mathrm{C}$ for $5 \mathrm{sec}$ and $60^{\circ} \mathrm{C}$ for $1 \mathrm{~min}$. The fluorescence signals were detected with an ABI 7900HT Version 2.3 sequence detection system (Applied Biosystems). The cycle threshold $(\mathrm{Ct})$ values for each gene were determined and the gene expression data were normalized to the endogenous control $\beta$-actin. The relative mRNA expression levels were calculated via the comparative threshold cycle $(\Delta \mathrm{Ct})$ method, where $\Delta \mathrm{Ct}$ is the difference in $\mathrm{Ct}$ value between the target gene and $\beta$-actin. All samples were analyzed in triplicate. The gene-specific primers used for qRT-PCR are listed in Table I.

Data analysis. The values are presented as the means \pm standard deviation ( $\mathrm{SD} ; \mathrm{n} \geq 4)$. Statistical comparisons were performed with SPSS PASW Statistics 18. One-way ANOVA and Student's t-test were carried out to determine statistical significance. P-values $<0.05$ were considered to indicate statistically significant differences. 
Table I. Primer sequences used for quantitative real-time PCR.

\begin{tabular}{ll}
\hline Gene & \multicolumn{1}{c}{ Primer sequences (5' to 3') } \\
\hline$\beta$-actin & $\begin{array}{l}\text { Forward: AGTTGCGTTACACCCTTTCTTG } \\
\text { Reverse: CACCTTCACCGTTCCAGTTTT }\end{array}$ \\
Bid & Forward: AGTCACACGCCGTCCTTGCT \\
& Reverse: GCTGTGACCACATCAAGCTTTAGCC \\
Caspase-3 & Forward: TGTGAGGCGGTTGTGGAAGAGT \\
& Reverse: AATGGGGGAAGAGGCAGGTGCA \\
Caspase-8 & Forward: TGTCCTTCCTGAGGGAGCTGCT \\
& Reverse: TGAGCCCTGCCTGGTGTCTGAA \\
Caspase-9 & Forward: TGGAGGATTTGGTGATGTCGAGCA \\
& Reverse: ATCTGGCTCGGGGTTACTGCCA \\
\hline
\end{tabular}

Table II. Effect of rhein on the survival rate of HUVECs.

Concentration of rhein $(\mu \mathrm{mol} / \mathrm{l})$

\begin{tabular}{lllllll}
\hline 0 (control) & 2 & 4 & 8 & 16 & 32 & 64 \\
\hline
\end{tabular}

\begin{tabular}{|c|c|c|c|}
\hline Survival rate $(\%)$ & $100.00 \pm 3.01$ & $97.50 \pm 1.78$ & $96.97 \pm 1.44$ \\
\hline
\end{tabular}

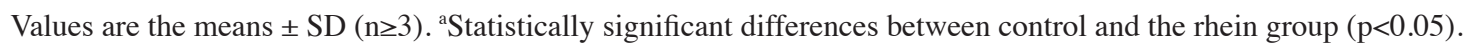

Table III. Protective effect of rhein against $\mathrm{H}_{2} \mathrm{O}_{2}$ injury in HUVECs.

\begin{tabular}{|c|c|c|c|c|c|c|c|}
\hline & \multirow[b]{2}{*}{$\begin{array}{l}\mathrm{H}_{2} \mathrm{O}_{2} \\
\text { group }\end{array}$} & \multicolumn{6}{|c|}{ Concentration of rhein $(\mu \mathrm{mol} / \mathrm{l})$} \\
\hline & & $\begin{array}{c}0 \\
\text { (control) }\end{array}$ & 1 & 2 & 4 & 8 & 16 \\
\hline Survival rate $(\%)$ & $100.00 \pm 2.14$ & $75.27 \pm 1.48^{\mathrm{a}}$ & $75.42 \pm 1.47$ & $78.00 \pm 1.17^{\mathrm{b}}$ & $80.08 \pm 1.08^{b}$ & $82.30 \pm 1.03^{\mathrm{b}}$ & $88.46 \pm 0.70^{b}$ \\
\hline
\end{tabular}

\section{Results}

Effect of rhein on the proliferation of HUVECs. To exclude rhein cytotoxicity against HUVECs, its effects on the proliferation of HUVECs were examined in the present study. As shown in Table II, 64 and $32 \mu \mathrm{mol} / 1$ of rhein significantly inhibited the proliferation of HUVECs $(\mathrm{p}<0.05)$. However, cell viability was not significantly different between cells treated with rhein $(2,4$, 8 and $16 \mu \mathrm{mol} / \mathrm{l}$ ) and the control. Thus, no more than $16 \mu \mathrm{mol} / 1$ of rhein was selected for the subsequent studies.

Protective effects of rhein against $\mathrm{H}_{2} \mathrm{O}_{2}$ injury in $\mathrm{HUVECs}$. As shown in Table III, following exposure to $200 \mu \mathrm{mol} / 1$ of $\mathrm{H}_{2} \mathrm{O}_{2}$, the cell viability of HUVECs decreased significantly $(\mathrm{p}<0.05)$ and the survival rate was $75.3 \%$. However, pre-incubation with different rhein concentrations $(2,4,8$ and $16 \mu \mathrm{mol} / \mathrm{l})$ significantly increased the viability of the $\mathrm{H}_{2} \mathrm{O}_{2}$-treated HUVECs in a dose-dependent manner $\left(\mathrm{R}^{2}=0.9704\right)$ and the survival rates were $78.0,80.1,82.3$ and $88.5 \%$, respectively. These results suggest that rhein protected HUVECs from oxidative stress-related cellular injury.

Influence of rhein on LDH, MDA, NOS, NO, SOD and GSH-PX of HUVECs. Currently, LDH is used mainly as an indicator for cell damage. Elevated LDH levels usually indicate cell damage. As shown in Fig. 1A, the percentage of LDH released by the HUVECs was $36.51 \%$ in the control, which was significantly increased to $54.89 \%$ after $8 \mathrm{~h}$ of exposure to $200 \mu \mathrm{mol} / 1$ of $\mathrm{H}_{2} \mathrm{O}_{2}(\mathrm{p}<0.05)$. However, pre-treatment with different rhein concentrations $(2,4,8$ and $16 \mu \mathrm{mol} / \mathrm{l})$ for $24 \mathrm{~h}$ significantly attenuated the $\mathrm{H}_{2} \mathrm{O}_{2}$-induced increase in $\mathrm{LDH}$ release $(\mathrm{p}<0.05)$ : $\mathrm{LDH}$ release $(\%)=$ release of $\mathrm{LDH}$ in the supernatant/(release of LDH in the supernatant + release of LDH from the cell lysate). 

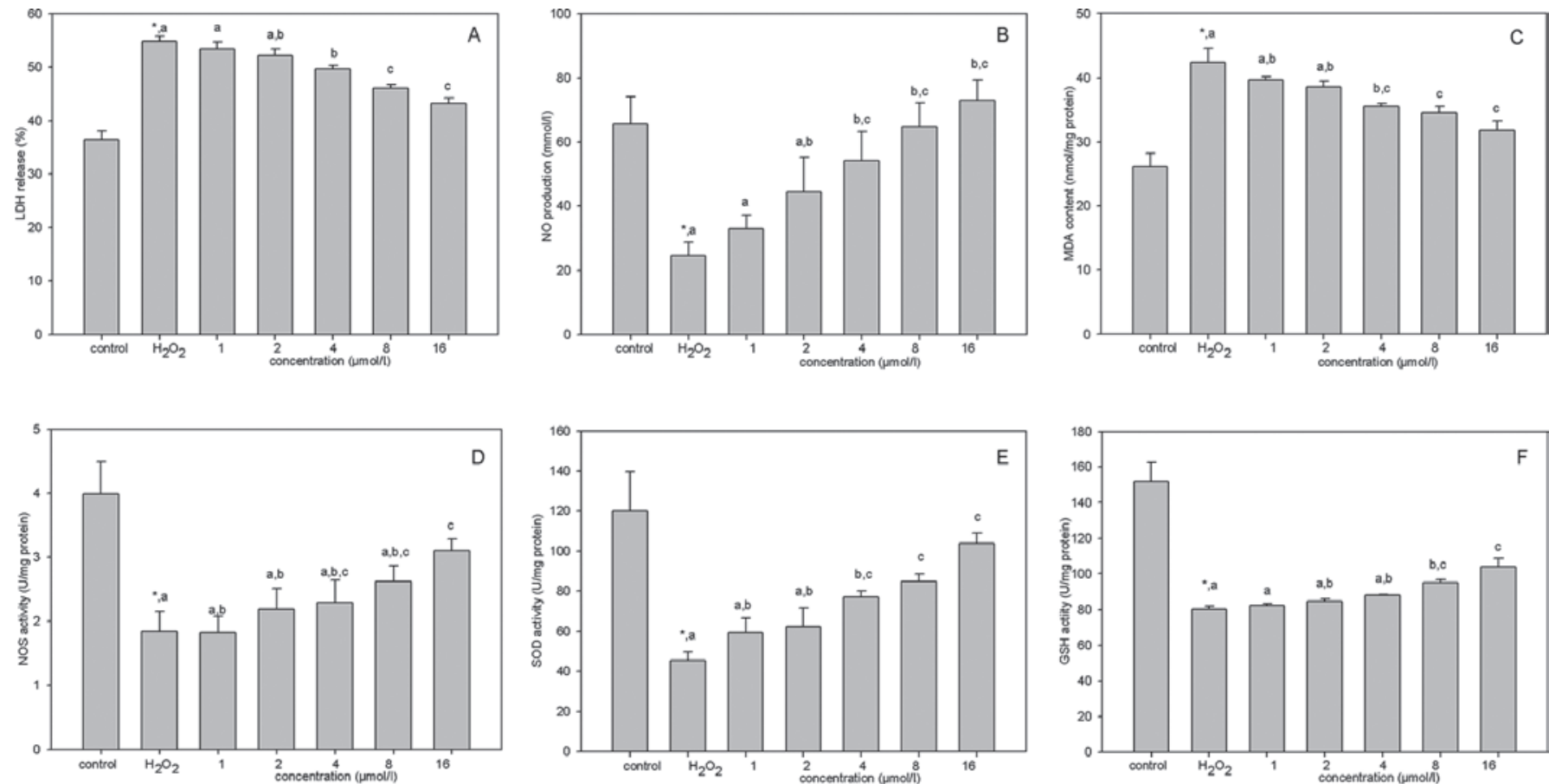

Figure 1. Effect of rhein on LDH, MDA, NO, NOS, SOD and GSH-PX activity in HUVECs. "Statistically significant differences between the control and the $\mathrm{H}_{2} \mathrm{O}_{2}$ group $(\mathrm{p}<0.05) ;{ }^{\mathrm{a}, \mathrm{b}, \mathrm{c}}$ statistically significant differences between the $\mathrm{H}_{2} \mathrm{O}_{2}$ and rhein groups $(\mathrm{p}<0.05)$.

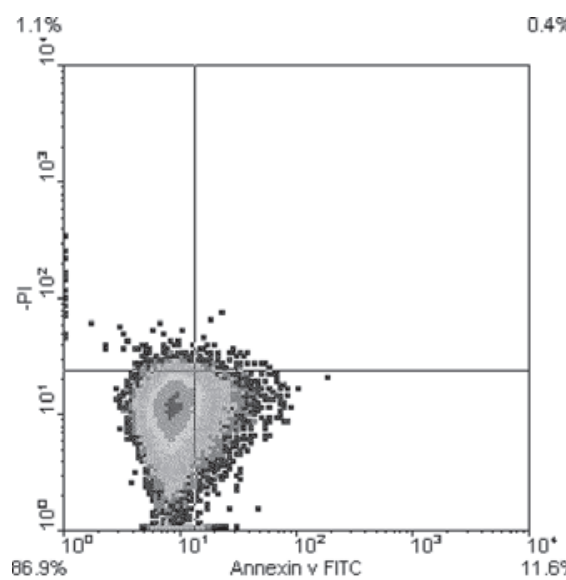

A

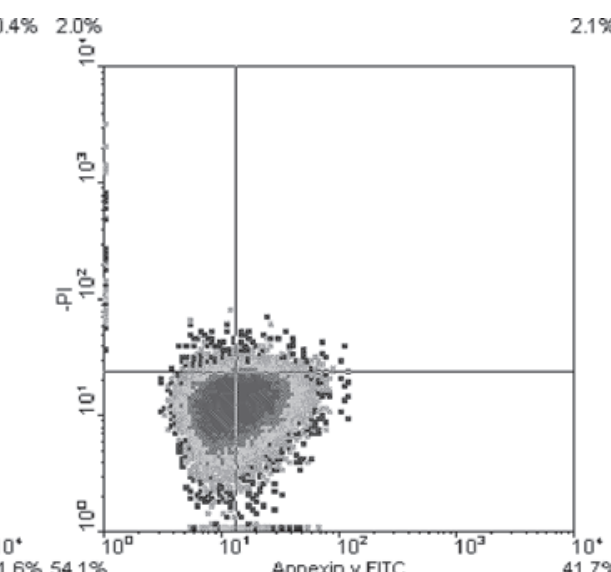

B
$2.1 \% 0.4 \%$

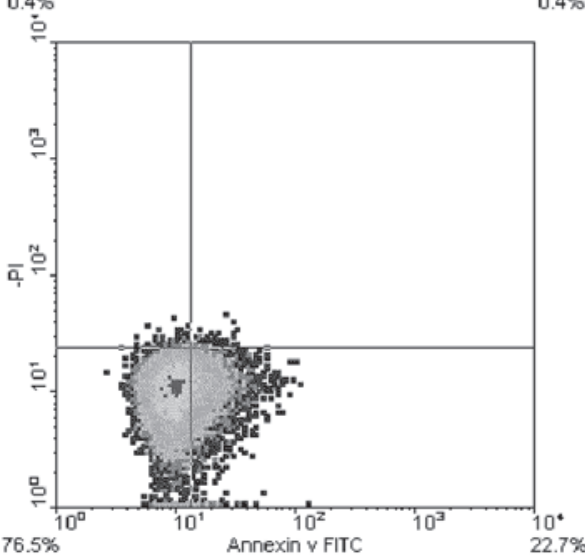

$\mathrm{C}$

Figure 2. Analysis of HUVEC apoptosis by flow cytometry using Annexin V-FITC and PI. Quadrant analysis of fluorescence intensity of gated cells in Annexin V-FITC and PI channels was from 20,000 events. (A) Control; (B) $\mathrm{H}_{2} \mathrm{O}_{2}$ group; (C) rhein group (16 $\mu$ mol/1).

$\mathrm{NO}$ is a molecule that has gained recognition as a crucial modulator of vascular disease, and one of the hallmarks of damaged endothelium is diminished levels of bioavailable NO, which is catalyzed by NOS (16). In the present study, NO release and NOS activity were assayed. Compared to the control, NO production and NOS activity were significantly decreased in the $\mathrm{H}_{2} \mathrm{O}_{2}$ group $(\mathrm{p}<0.05)$, which led to nitrosative stress indirectly. Nitrosative stress also plays an important role in AS. Nitrosative stress is induced whenever conditions are favorable for increased superoxide formation and NO is locally available. Superoxides react with NO, forming peroxynitrite $\left(\mathrm{ONOO}^{-}\right)$, which rapidly causes protein nitration or nitrosylation, lipid peroxidation, DNA damage and cell death. Ideal therapeutic approaches for nitrosative stress in AS should limit the formation of superoxides and $\mathrm{ONOO}^{-}$, while preventing reductions in vascular NO that would cause vasoconstriction (17). Following pre-treatment with different rhein concentrations $(2,4,8$ and $16 \mu \mathrm{mol} / \mathrm{l})$ for $24 \mathrm{~h}$, the decrease in $\mathrm{H}_{2} \mathrm{O}_{2}$-induced NO production and NOS activity were inhibited in a dose-dependent manner (Fig. 1B and D).

ROS degrades polyunsaturated lipids, forming MDA.MDA is one of the most frequently used indicators of lipid peroxidation (18), which is indirectly involved in the degree of damage to cells. The MDA concentration was $26.15 \pm 2.02 \mathrm{nmol} /$ $\mathrm{mg}$ protein in the control. Addition of $200 \mu \mathrm{mol} / 1$ $\mathrm{H}_{2} \mathrm{O}_{2}$ caused a significant increase in MDA production $(42.38 \pm 2.16 \mathrm{nmol} / \mathrm{mg}$ protein, $\mathrm{p}<0.05)$. MDA concentration decreased significantly after the cells were pre-treated with different concentrations of rhein $(2,4,8$ and $16 \mu \mathrm{mol} / \mathrm{l})$ for $24 \mathrm{~h}(\mathrm{p}<0.05$, Fig. 1C). 


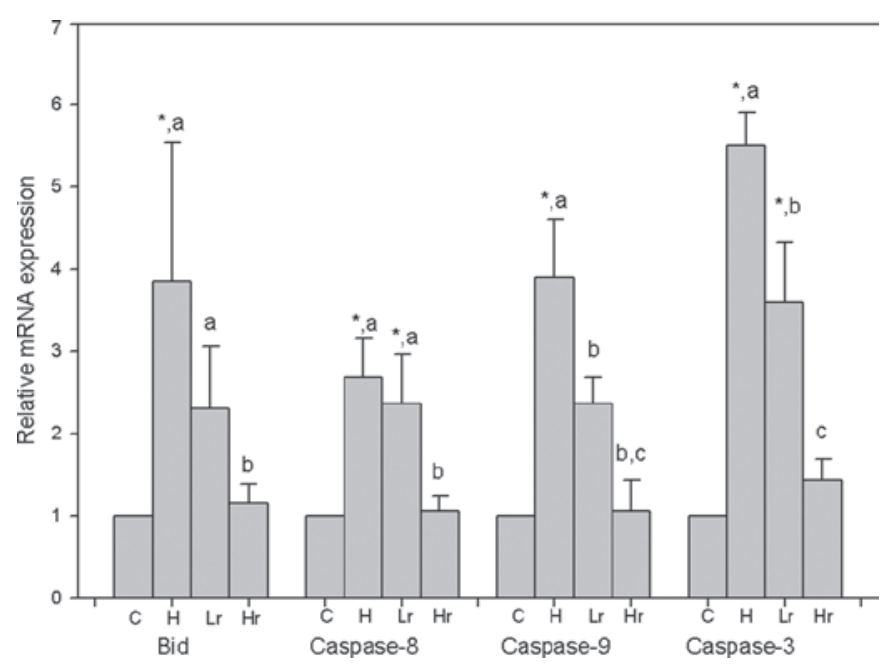

Figure 3. Effect of rhein on the mRNA expression levels of $\mathrm{H}_{2} \mathrm{O}_{2}$-induced Bid and caspase $-3,-8$ and -9 in HUVECs. *Statistically significant differences between the control and the $\mathrm{H}_{2} \mathrm{O}_{2}$ group $(\mathrm{p}<0.05)$; ${ }^{\mathrm{a}, \mathrm{b}, \mathrm{c}}$ statistically significant differences between the $\mathrm{H}_{2} \mathrm{O}_{2}$ group and the rhein group $(\mathrm{p}<0.05)$. C, control; $\mathrm{H}, \mathrm{H}_{2} \mathrm{O}_{2}$ group; $\mathrm{Lr}$, low rhein concentration $(4 \mu \mathrm{mol} / \mathrm{l})$; Hr, high rhein concentration $(16 \mu \mathrm{mol} / 1)$

To protect cells from the damage caused by ROS, organisms have developed several defense mechanisms to remove ROS, which include antioxidant enzymes, such as SOD and GSH-PX. SOD catalyzes the dismutation of superoxide into $\mathrm{H}_{2} \mathrm{O}_{2}$, whereas GSH-PX converts $\mathrm{H}_{2} \mathrm{O}_{2}$ to water (19). The activities of SOD and GSH-PX are shown in Fig. $1 \mathrm{E}$ and $\mathrm{F}$. The activities of SOD $(45.43 \pm 4.21 \mathrm{U} / \mathrm{mg}$ protein $)$ and GSH-PX $(80.16 \pm 1.56 \mathrm{U} / \mathrm{mg}$ protein) were significantly decreased in the $\mathrm{H}_{2} \mathrm{O}_{2}$ group compared to the control $(120.08 \pm 19.62$ and $151.82 \pm 10.71$, respectively; $\mathrm{p}<0.05)$, whereas pre-treatment with different rhein concentrations significantly increased the SOD and GSH-PX activity in the HUVECs in a dosedependent manner (Fig. 1E and F). The results show that rhein protects HUVECs against the damage caused by $\mathrm{H}_{2} \mathrm{O}_{2}$.

Effect of rhein on HUVEC apoptosis. The analysis was performed as described by Mukherjee et al (20). As shown in Fig. 2, the cells were gated in four quadrants. The cells in the lower right (LR) and upper right (UR) were considered early apoptotic (Annexin ${ }^{+} / \mathrm{PI}^{-}$) and late apoptotic $\left(\right.$Annexin ${ }^{+} / \mathrm{PI}^{+}$), respectively, whereas the cells in the lower left and upper left quadrants were considered live and necrotic, respectively. The extent of apoptosis was expressed as the total of the percentages in the quadrants.

As shown in Fig. 2A, the percentages of apoptotic cells were $0.4 \%$ (UR) and $11.6 \%$ (LR) in the control. Following exposure to $200 \mu \mathrm{mol} / 1 \mathrm{H}_{2} \mathrm{O}_{2}$ for $8 \mathrm{~h}$, the percentage of apoptosis increased to $2.1 \%$ (UR) and $41.7 \%$ (LR), respectively (Fig. 2B). However, pre-incubation with rhein (16 $\mu \mathrm{mol} / \mathrm{l})$ for $24 \mathrm{~h}$ arrested the apoptosis induced by $\mathrm{H}_{2} \mathrm{O}_{2}$ exposure, and the values of apoptosis were decreased to $0.7 \%$ (UR) and $22.7 \%$ (LR) (Fig. 2C). The results suggest that rhein has protective effects against oxidative stress-related cellular injury by decreasing the apoptosis rate.

Effect of rhein on the mRNA expression of Bid and caspases in HUVECs. To explore the anti-apoptotic mechanism of rhein, the
mRNA expression levels of Bid and caspase- $-3,-8$ and -9 were measured by qRT-PCR. The results indicate that the mRNA expression levels of all genes were significantly upregulated in the $\mathrm{H}_{2} \mathrm{O}_{2}$ group compared to the control ( $\mathrm{p}<0.05$, Fig. 3). Cells pre-treated with high rhein concentrations ameliorated the upregulation of mRNA expression induced by $\mathrm{H}_{2} \mathrm{O}_{2}$ ( $\mathrm{p}<0.05$, Fig. 3).

\section{Discussion}

Endothelial cell injury caused by ROS plays a critical role in the pathogenesis of AS. The indicators of oxidative stress-related cell injury (LDH, MDA, NO, NOS, SOD and GSH-PX) were measured in the present study. The results indicate that the cells treated with $\mathrm{H}_{2} \mathrm{O}_{2}$ had markedly increased MDA and LDH content and decreased NO content and NOS, SOD and GSH-PX activity $(\mathrm{p}<0.05)$. However, pre-treatment with different rhein concentrations $(2,4,8$ and $16 \mu \mathrm{mol} / \mathrm{l})$ decreased their MDA and LDH content and increased the NO content and NOS, SOD and GSH-PX activity in a dose-dependent manner. These findings suggest that rhein protects against HUVECs through anti-oxidation, which is beneficial for the prevention and treatment of AS.

In addition, AS is characterized by the excessive apoptosis of vascular endothelial cells (21). Oxidative stress in the vascular wall has been closely implicated in the excessive apoptosis of HUVECs (22). Therefore, the key point in the prevention and control of AS is inhibiting the excessive apoptosis of vascular endothelial cells induced by oxygen radicals. In the present study, high concentrations of $\mathrm{H}_{2} \mathrm{O}_{2}$ led HUVECs to undergo apoptosis, which is consistent with the findings of other studies $(23,24)$. However, the mechanisms of apoptosis are quite complex and are controlled by various pathways and signals (25). The underlying mechanisms of $\mathrm{H}_{2} \mathrm{O}_{2}$-induced HUVEC apoptosis involved apoptosis-related regulation signals, such as Bcl-2 and the caspase families (23). In mammals, members of the Bcl-2 and caspase families play cell-specific roles in apoptosis (26). Therefore, blockage of these pro-apoptotic pathways in HUVECs has been considered as an attractive therapeutic strategy to prevent or ameliorate the progression of AS induced by $\mathrm{H}_{2} \mathrm{O}_{2}$.

Caspases, a group of highly conserved, cysteine-dependent aspartate-specific proteases, play a central role in the regulation and execution of apoptosis. There are two types of caspases: initiator caspases, such as caspase-2, $-8,-9$ and -10 , and effector caspases, such as caspase-3, -7 and -6. Initiator caspases cleave inactive pro-forms of effector caspases and thereby activate them. Effector caspases in turn cleave other protein substrates at aspartate residues within the cell. The overexpression of the above genes triggers the apoptotic process (27). In the present study, the expression levels of caspase-3,-8 and -9 mRNA were low in the control, but were significantly upregulated when endothelial cells were treated with $\mathrm{H}_{2} \mathrm{O}_{2}(\mathrm{p}<0.05)$. Notably, the addition of rhein ameliorated the upregulation of caspase-3, -8 and -9 mRNA ( $<<0.05$, Fig. 3), which indicates that one of the anti-apoptotic mechanisms of rhein is a caspase-dependent pathway.

Bid is a member of the Bcl-2 family that belongs to the 'BH3 domain-only' pro-apoptotic regulators. Caspase-8 cleaves the cytoplasmic Bid protein into truncated Bid (tBid), which translocates to the mitochondria and causes the release 
of caspase-activating factors from the mitochondria, thereby inducing cell apoptosis $(28,29)$. The expression levels of Bid mRNA were significantly upregulated in the $\mathrm{H}_{2} \mathrm{O}_{2}$ group compared to the control $(\mathrm{p}<0.05)$. However, high rhein concentrations ameliorated the upregulation of $\mathrm{H}_{2} \mathrm{O}_{2}$-induced Bid mRNA expression ( $p<0.05$, Fig. 3), which suggests that the Bcl-2 pathway may be another anti-apoptotic mechanism of rhein.

Caspase activation is a crucial early event in cells undergoing apoptosis and the Bcl-2 family is involved in a distal apoptotic pathway. In the present study, rhein appeared to switch off the apoptotic cascade pathway by inhibiting the activation of Bid and caspase-3, -8 and -9 . These findings suggest that rhein protects $\mathrm{H}_{2} \mathrm{O}_{2}$-injured HUVECs by interrupting the apoptotic cascade pathway of the caspase and Bcl-2 families, which may be an anti-apoptotic mechanism of rhein (30).

In conclusion, rhein has anti-oxidative effects on HUVECs; it directly inhibits the intracellular ROS generation stimulated by $\mathrm{H}_{2} \mathrm{O}_{2}$, downregulates the expression of $\mathrm{Bid}$ and caspase-3, -8 and -9 mRNA, and decreases endothelial cell apoptosis. The findings of the present study may provide a pharmacological basis for the clinical application of rhein in the treatment of atherosclerosis.

\section{Acknowledgements}

The authors would like to thank the Free Exploration and the Research Program of State Key Laboratory of Food Science and Technology, Nanchang University (Project No. SKLF-TS200921 and SKLF-MB-201003) for their financial support.

\section{References}

1. Warboys CM, Amini N, de Luca A and Evans PC: The role of blood flow in determining the sites of atherosclerotic plaques. F1000 Med Rep 3: 5, 2011.

2. Kardakaris R, Gareus R, Xanthoulea $S$ and Pasparakis $M$ : Endothelial and macrophage-specific deficiency of P38 $\alpha$ MAPK does not affect the pathogenesis of atherosclerosis in $\mathrm{ApoE}^{-/}$ mice. PLoS One 6: e21055, 2011.

3. Harrison CM, Pompilius M, Pinkerton KE and Ballinger SW: Mitochondrial oxidative stress significantly influences atherogenic risk and cytokine-induced oxidant production. Environ Health Perspect 119: 676-681, 2011.

4. De Caterina RD, Massaro M, Scoditti E and Annunziata Carluccio M: Pharmacological modulation of vascular inflammation in atherothrombosis. Ann NY Acad Sci 1207: 23-31, 2010.

5. Wang YK, Hong YJ, Wei M, Wu Y, Huang ZQ, Chen RZ and Chen HZ: Curculigoside attenuates human umbilical vein endothelial cell injury induced by $\mathrm{H}_{2} \mathrm{O}_{2}$. J Ethnopharmacol 132: 233-239, 2010.

6. Wang B, Peng L, Zhu L and Ren P: Protective effect of total flavonoids from Spirodela polyrrhiza (L.) Schleid on human umbilical vein endothelial cell damage induced by hydrogen peroxide. Colloids Surf B Biointerfaces 60: 36-40, 2007.

7. Jiang B, Liang P, Zhang B, Song J, Huang X and Xiao X: Role of PPAR-beta in hydrogen peroxide-induced apoptosis in human umbilical vein endothelial cells. Atherosclerosis 204: 353-358, 2009.

8. Qian J, Jiang F, Wang B, Yu Y, Zhang X, Yin Z and Liu C: Ophiopogonin D prevents $\mathrm{H}_{2} \mathrm{O}_{2}$-induced injury in primary human umbilical vein endothelial cells. J Ethnopharmacol 128: 438-445, 2010.

9. Antunes F and Cadenas E: Cellular titration of apoptosis with steady state concentrations of $\mathrm{H}_{2} \mathrm{O}_{2}$ : submicromolar levels of $\mathrm{H}_{2} \mathrm{O}_{2}$ induce apoptosis through Fenton chemistry independent of the cellular thiol state. Free Redical Bio Med 30: 1008-1018, 2001.
10. Zhao YL, Zhou GD, Yang HB, Wang JB, Shan LM, Li RS and Xiao XH: Rhein protects against acetaminophen-induced hepatic and renal toxicity. Food Chem Toxicol 49: 1705-1710, 2011.

11. Irshad M, Shreaz S, Manzoor N, Khan LA and Rizvi MM: Anticandidal activity of Cassia fistula and its effect on ergosterol biosynthesis. Pharm Biol 49: 727-733, 2011.

12. Fernand VE, Losso JN, Truax RE, Villar EE, Bwambok DK, Fakayode SO, Lowry M and Warner IM: Rhein inhibits angiogenesis and the viability of hormone-dependent and -independent cancer cells under normoxic or hypoxic conditions in vitro. Chem Biol Interact 192: 220-232, 2011.

13. Spencer CM and Wilde MI: Diacerein. Drugs 53: 98-106, 1997.

14. Heo SK, Yun HJ, Park WH and Park SD: Rhein inhibits TNF-alpha-induced human aortic smooth muscle cell proliferation via mitochondrial-dependent apoptosis. J Vasc Res 46: 375-386, 2009.

15. Kocaman SA, Yalçın MR, Yağcı M, et al: Endothelial progenitor cells $\left(\mathrm{CD} 34^{+} \mathrm{KDR}^{+}\right)$and monocytes may provide the development of good coronary collaterals despite the vascular risk factors and extensive atherosclerosis. Anadolu Kardiyol Derg 11: 290-299, 2011.

16. Napoli C, de Nigris F, Williams-Ignarro S, Pignalosa O, Sica V and Ignarro LJ: Nitric oxide and atherosclerosis: an update. Nitric Oxide 15: 265-279, 2006.

17. Bixby M, Spieler L, Menini T and Gugliucci A: Ilex paraguariensis extracts are potent inhibitors of nitrosative stress: a comparative study with green tea and wines using a protein nitration model and mammalian cell cytotoxicity. Life Sci 77: 345-358, 2005.

18. Roebuck KA: Oxidant stress regulation of IL-8 and ICAM-1 gene expression: differential activation and binding of the transcription factors AP-1 and NF- $\varkappa$ B (Review). Int J Mol Med 4: 223-230, 1999.

19. Ugusman A, Zakaria Z, Hui CK and Nordin NA: Piper sarmentosum inhibits ICAM-1 and Nox4 gene expression in oxidative stress-induced human umbilical vein endothelial cells. BMC Complement Altern Med 11: 31, 2011.

20. Mukherjee A, Dutta S, Shanmugavel M, Mondhe DM, Sharma PR, Singh SK, Saxena AK and Sanyal U: 6-Nitro-2(3-hydroxypropyl)-1H-benz[de]isoquinoline-1,3-dione, a potent antitumor agent, induces cell cycle arrest and apoptosis. J Exp Clin Cancer Res 29: 175, 2010.

21. González-Navarro $\mathrm{H}$, Abu Nabah YN, Vinué A, Andrés-Manzano MJ, Collado M, Serrano M and Andrés V: p19(ARF) deficiency reduces macrophage and vascular smooth muscle cell apoptosis and aggravates atherosclerosis. J Am Coll Cardiol 55: 2258-2268, 2010.

22. Park S, Kim JA, Choi S and Suh SH: Superoxide is a potential culprit of caspase-3 dependent endothelial cell death induced by lysophosphatidylcholine. J Physiol Pharmacol 61: 375-381, 2010.

23. Liu H, He J, Li W, Yang Z, Wang Y, Bai X, Yu C and Du Y: Chitosan oligosaccharides protect human umbilical vein endothelial cells from hydrogen peroxide-induced apoptosis. Carbohyd Polym 80: 1062-1071, 2010.

24. Hwang DY, Sin JS, Kim MS, et al: Overexpression of human selenoprotein $\mathrm{M}$ differentially regulates the concentrations of antioxidants and $\mathrm{H}_{2} \mathrm{O}_{2}$, the activity of antioxidant enzymes, and the composition of white blood cells in a transgenic rat. Int $\mathrm{J}$ Mol Med 2: 169-179, 2008.

25. Châtel A, Hamer B, Jakšić Z, Vucelić V, Talarmin H, Dorange G, Schröder HC and Müller WE: Induction of apoptosis in mussel Mytilus galloprovincialis gills by model cytotoxic agents. Ecotoxicology 20: 2030-2041, 2011.

26. Leonard JR, D'Sa C, Cahn BR, Korsmeyer SJ and Roth KA: Bid regulation of neuronal apoptosis. Brain Res Dev Brain Res 128: 187-190, 2001.

27. Luo X, Budihardjo I, Zou H, Slaughter C and Wang X: Bid, a $\mathrm{Bcl} 2$ interacting protein, mediates cytochrome $\mathrm{c}$ release from mitochondria in response to activation of cell surface death receptors. Cell 94: 481-490, 1998.

28. Baumgartner HK, Gerasimenko JV, Thorne C, et al: Caspase-8mediated apoptosis induced by oxidative stress is independent of the intrinsic pathway and dependent on cathepsins. Am J Physiol Gastrointest Liver Physiol 293: 296-307, 2007.

29. Kantari $\mathrm{C}$ and Walczak H: Caspase- 8 and bid: caught in the act between death receptors and mitochondria. Biochim Biophys Acta 1813: 558-563, 2011.

30. Schlecht-Bauer D, Antier D, Machet MC and Hyvelin JM: Shortand long-term cardioprotective effect of darbepoetin-alpha: role of Bcl-2 family proteins. J Cardiovasc Pharmacol 54: 223-231, 2009. 